\title{
Możliwości poprawy jakości owoców truskawki metodą hybrydyzacji wewnątrz- i międzygatunkowej w obrębie rodzaju Fragaria
}

\author{
Possibilities of improvement the quality of strawberry fruit by intra- and interspecific \\ hybridization within the Fragaria genus
}

Agnieszka Masny ${ }^{1 \oplus 凶}$, Monika Mieszczakowska-Frąc ${ }^{2 \oplus}$

\author{
1Zakład Hodowli Roślin Ogrodniczych, Instytut Ogrodnictwa, ul. Konstytucji 3 Maja 1/3, 96-100 Skierniewice, \\ 2Zakład Przechowalnictwa i Przetwórstwa Owoców i Warzyw, Instytut Ogrodnictwa, \\ ul. Konstytucji 3 Maja 1/3, 96-100 Skierniewice, \\ $\bowtie$ e-mail: agnieszka.masny@inhort.pl
}

\begin{abstract}
Prace badawcze nad poszerzaniem zmienności genetycznej u truskawki na świecie ukierunkowane są głównie na poprawę zewnętrznej i wewnętrznej jakości owoców. Celem podjętych w Instytucie Ogrodnictwa badań było określenie możliwości zwiększenia zawartości substancji bioaktywnych (przede wszystkim polifenoli, antocyjanów oraz kwasów organicznych) w owocach truskawki metodą hodowli konwencjonalnej. Na podstawie dwuletniej oceny fenotypowej spośród 6097 siewek, otrzymanych w wyniku krzyżowań wewnątrz- i międzygatunkowych w obrębie rodzaju Fragaria, wyselekcjonowano 90 wartościowych genotypów. W roku 2019 genotypy te oceniono pod względem plonu, masy, atrakcyjności i jędrności owoców, a także zawartości w owocach ekstraktu, związków fenolowych, antocyjanów i kwasu askorbinowego.

Stwierdzono, że największe, najbardziej atrakcyjne i jędrne owoce wytworzyły klony T-201536-16 i T-201536-08 ('Clery' × 'Grandarosa'), T-201514-04 i T-201514-05 ('Candiss' × 'Panvik') oraz T-201560-07 ('Onda' × 'Panvik'). Największą zawartością ekstraktu odznaczały się owoce genotypów T-201536-16 i T-201536-09 ('Clery' × 'Grandarosa'). Najwięcej związków fenolowych zawierały owoce klonów T-201501-02 ('Alba' × 'Grandarosa'), T-201512-04 ('Camarosa' × 'Panvik') oraz T-201567-01 ('Patty’ × 'Panvik'), zaś antocyjanów - owoce klonów T-20151408 ('Candiss' × 'Panvik'), T-201508-01 ('Alice' × 'Matis'), T-201517-05 ('Chandler' × 'Matis') oraz T-201580-01 (Fragaria chiloensis Del Norte $\times$ 'Elsanta'). Najbardziej bogate w kwas askorbinowy były owoce klonów T-20152605 ('Cigaline' $\times$ 'Grandarosa'), T-201501-03 ('Alba' × 'Grandarosa'), T-201536-15 ('Clery' × 'Grandarosa') oraz T-201567-01 ('Patty' × 'Panvik'). Najwyższą łączną zawartością wszystkich analizowanych związków bioaktywnych w owocach odznaczały się klony T-201514-08 ('Candiss' × 'Panvik'), T-201517-05 ('Chandler' × 'Matis') oraz T-201567-04 ('Patty' × 'Panvik').
\end{abstract}

Słowa kluczowe: antocyjany, jakość owoców, kwas L-askorbinowy, polifenole, truskawka

Research on widening genetic variation in strawberry around the world is focused mainly on improving external and internal fruit quality. The aim of the research undertaken at the Research Institute of Horticulture was to determine the possibility of increasing the content of bioactive compounds (polyphenols, anthocyanins and organic acids) in strawberry by conventional breeding. Based on a two-year phenotypic evaluation, 90 valuable genotypes were selected from 6097 hybrids obtained as a result of intra- and interspecific hybridization within the Fragaria genus. In 2019, these genotypes were assessed in terms of fruit yield, weight, attractiveness and firmness, as well as the content of the extract, phenolic compounds, anthocyanins and ascorbic acid in the fruit.

We found that the largest, most attractive and firmest fruits were produced by clones T-201536-16 and T-201536-08 ('Clery' $\times$ 'Grandarosa'), T-201514-04 and T-201514-05 ('Candiss' $\times$ 'Panvik') and T-201560-07 ('Onda' × 'Panvik'). The highest extract content was noted in the fruits of genotypes T-201536-16 and T-201536-09 ('Clery' $\times$ 'Grandarosa'). The greatest number of phenolic compounds were encountered in the fruits of clones T-201501-02 ('Alba' × 'Grandarosa'), T-201512-04 ('Camarosa' × 'Panvik') and T-201567-01 ('Patty' × 'Panvik'), while the highest anthocyanin levels were evident in the fruit of clones T-201514-08 ('Candiss' $x$ 'Panvik'), T-201508-01 ('Alice' $\times$ 'Matis'), T-201517-05 ('Chandler' $\times$ 'Matis') and T-201580-01 (Fragaria chiloensis Del Norte $\times$ 'Elsanta'). Moreover, the richest levels of ascorbic acid were in the fruits of clones T-201526-05 ('Cigaline' $\times$ 'Grandarosa'), T-201501-03 ('Alba' × 'Grandarosa'), T-201536-15 ('Clery' × 'Grandarosa') and T-201567-01 ('Patty' × 'Panvik'). Finally, the highest total content of all analyzed bioactive compounds in fruits was noted for clones T-201514-08 ('Candiss' × 'Panvik'), T-201517-05 ('Chandler' × 'Matis') and T-201567-04 ('Patty' × 'Panvik').

Key words: anthocyanins, fruit quality, L-ascorbic acid, polyphenols, strawberry 


\section{Wstęp}

Polska należy do grona największych producentów i eksporterów truskawek w świecie. W ostatnich latach w naszym kraju produkuje się ok. 180-200 tys. ton tych owoców (dane za lata 20132018). Według FAOSTAT (dane za 2017 r.), z taką wielkością produkcji Polska zajmuje drugie miejsce w Europie i siódme w świecie. Aby utrzymać tak wysoką pozycję, prace badawcze nad poprawieniem jakości truskawek powinny uwzględniać trendy europejskie, wśród których najważniejsza jest obecnie poprawa jakości życia i zdrowia mieszkańców Europy. W sadownictwie szczególny nacisk kładziony jest na poprawę właściwości odżywczych i prozdrowotnych owoców poprzez zwiększenie w nich zawartości substancji bioaktywnych (Capocasa i in., 2008 a, b). Związki te, znane $\mathrm{z}$ właściwości antyoksydacyjnych i antykancerogennych, pełnia bardzo istotna rolę $\mathrm{w}$ diecie człowieka, zwłaszcza w zapobieganiu chorobom nowotworowym, miażdżycy i cukrzycy oraz nadciśnieniu tętniczemu (Battino i in., 2009; 2017; Mirończuk-Chodakowska i in., 2011; Giampieri i in., 2012; Bialasiewicz i in., 2014; Zasowska i in., 2016). Szczególne znaczenie $w$ profilaktyce tych chorób przypisuje się związkom z grupy polifenoli, flawonoidom i antocyjanom, kwasowi askorbinowemu oraz oligomerom kwasu elagowego - elagotaninom (da Silva-Pinto i in., 2008; Kazimierczak i in., 2009; Marques i in., 2010; Prymont-Przymińska i in., 2016).

Truskawki, podobnie jak i inne owoce jagodowe, są uznawane za bardzo ważne źródło związków bioaktywnych. Jednakże zawartość tych związków w bardzo dużym stopniu zależy od genotypu/ odmiany (Wang i Lewers, 2007). Bogate w związki bioaktywne są owoce odmian 'Clery', 'Diana', 'Selvik' (Michalska i in., 2017), 'Manille', 'Matis', 'Asia', 'Camarosa', 'Alice', 'Roxana', 'Madeleine', 'Cifrance', 'Patty' i 'Dora' (Capocasa i in., 2008 b), a także 'Alba', 'Sveva', 'Marina', 'Darselect', 'Elsanta', 'Honeoye' i 'Panvik' (EUBerry germplasm database, 2014). Jednak znacznie więcej związków bioaktywnych, w porównaniu do wymienionych odmian uprawnych z gatunku Fragaria $\times$ ananas$s a$, zawierają owoce dzikich form $F$. chiloensis i $F$. virginiana (Wang i Lewers, 2007; Diamanti i in., 2012). Wyniki niektórych badań wskazują, że wykorzystanie puli genowej tych gatunków może skutkować zwiększeniem zawartości związków odżywczych i fitochemicznych w owocach truskawki (Capocasa i in., 2008 a).

Celem podjętych badań było określenie możliwości zwiększenia zawartości związków bioaktywnych (przede wszystkim polifenoli, antocyjanów oraz kwasów organicznych) w owocach truskawki metodą hodowli konwencjonalnej w oparciu o ocenę mieszańców uzyskanych w wyniku krzyżowań wewnątrz- i międzygatunkowych wybranych form rodzicielskich należących do rodzaju Fragaria.

\section{Material i Metody}

Badania prowadzono w Instytucie Ogrodnictwa (IO) w Skierniewicach w roku 2019. Przedmiotem badań były owoce 90 mieszańców (klonów) truskawki, wyselekcjonowanych i rozmnożonych w roku 2017 po dwuletniej ocenie 6097 siewek pokolenia $\mathrm{F}_{1}$, uzyskanych $\mathrm{W}$ wyniku krzyżowań wewnątrz- i międzygatunkowych wybranych form rodzicielskich z rodzaju Fragaria, odznaczających się wysoką zawartością w owocach składników bioaktywnych, głównie kwasu askorbinowego, antocyjanów i polifenoli.

Doświadczenie porównawcze założono jesienią 2017 roku w Sadzie Pomologicznym IO w Skierniewicach na glebie płowej, IV klasy bonitacyjnej, średnio zasobnej w składniki pokarmowe. Szczegółowy wykaz genotypów wraz z ich rodowodami zamieszczono w Tabeli 1. Każdy z wyselekcjonowanych genotypów reprezentowany był przez 15 roślin, posadzonych $\mathrm{w}$ jednym powtórzeniu $\mathrm{w}$ rozstawie $1,1 \times 0,3 \mathrm{~m}$, w kolejności zgodnej $\mathrm{z}$ numeracją wyselekcjonowanych pojedynków. Wszystkie prace uprawowo-pielęgnacyjne wykonywano zgodnie z zaleceniami dla plantacji towarowych.

Dojrzewające owoce każdego klonu zbierano sukcesywnie w miarę ich dojrzewania (przeprowadzono łącznie 5 zbiorów owoców), a następnie sortowano na owoce zdrowe i porażone przez szarą pleśn. W każdym z terminów zbiorów oceniano wagowo wielkość plonu i masę owoców zdrowych, zaś bonitacyjnie - atrakcyjność i jędrność owoców, używając $w$ tym celu skali $1-5$, gdzie 1 oznacza najniższą wartość, zaś 5 - najwyższą wartość badanej cechy. Oceniając atrakcyjność owoców zwracano uwagę zwłaszcza na kształt owocu i jego wyrównanie (brak deformacji), barwę skórki oraz jej połysk. Po wykonaniu oceny plenności i jakości zewnętrznej, wszystkie owoce zebrane w każdym terminie zbioru umyto, usunięto $\mathrm{z}$ nich kielich, zapakowano w indywidualne torebki strunowe i umieszczono w zamrażarce w temperaturze $-25^{\circ} \mathrm{C}$ do czasu wykonywania analiz. Po zakończeniu zbiorów przygotowano próby mieszane owoców każdego genotypu i przekazano do Pracowni Przetwórstwa i Oceny Jakości Owoców i Warzyw Zakładu Przechowalnictwa i Przetwórstwa Owoców i Warzyw w celu wykonania podstawowych 
analiz składu chemicznego owoców. Bezpośrednio przed analizą owoce rozdrobniono za pomocą młynka Blixer 3. Stosowano stały $\mathrm{CO}_{2}$ lub ciekły $\mathrm{N}_{2}$ W zależności od wielkości dostarczonej próby. Powstała $\mathrm{w}$ ten sposób średnia próbka laboratoryjna została podzielona na dwa powtórzenia techniczne i poddana analizom chemicznym. W badanych próbach oznaczono następujące składniki:

1. Ekstrakt (ekstrakt ogólny): suma składników substancji nielotnych do temperatury 100 $\mathrm{oC}$, rozpuszczalnych $\mathrm{w}$ wodzie określona za pomocą refraktometru (RE 50, Mettler Toledo, Szwajcaria) według normy PN-90 A-75101/02;

2. Zawartość barwników antocyjanowych (ANT) - metodą różnicowego $\mathrm{pH}$ z zastosowaniem spektrofotometru UV/Vis CARY 300E (Varian) według Giusti i Wrolstad (2001). Pomiar absorbancji przy długości fali $520 \mathrm{~nm}$. Zawartość antocyjanów wyliczono na podstawie molowej absorbancji glukozydu-3-pelargonidyny (22400) i masy molowej - 433,2 g/mol, a wyniki wyrażono w mg/100 g świeżej masy owoców;

3. Zawartość związków fenolowych ogółem (TPC) oznaczono zmodyfikowaną metodą spektrofotometryczną (Tsao i Yang, 2003) przy użyciu odczynnika Folin-Ciocalteau. Ogólna zawartość związków fenolowych przy długości fali $765 \mathrm{~nm}$ wyrażona została $\mathrm{w}$ mg kwasu galusowego/100 g świeżej masy owocu;

4. Zawartość kwasu L-askorbinowego oznaczono metodą wysokosprawnej chromatografii cieczowej (Agilent 1200, detektor DAD) po ekstrakcji w 6\% kwasie metafosforowym. Rozdział prowadzono przy użyciu kolumny Supelco LC-18 z prekolumną. Warunki elucji: $0,8 \mathrm{ml} /$ min, temperatura 30 oC, długość fali $244 \mathrm{~nm}$ i $210 \mathrm{~nm}$, faza ruchoma $-1 \%$ bufor fosforanowy (K2HPO4) o $\mathrm{pH}=2,5 \mathrm{w}$ przepływie izokratycznym. Wyniki wyrażono $\mathrm{w} \mathrm{mg} / 100 \mathrm{~g}$ świeżej masy owoców.

\section{Wyniki i Dyskusja}

Plonowanie badanych genotypów było bardzo zróżnicowane; różnice dla poszczególnych genotypów wynosiły od 104 do $2802 \mathrm{~g} /$ poletko (Tab. 1). Przyczyną tak dużych różnic były przede wszystkim uszkodzenia przez przymrozki wiosenne pąków kwiatowych i kwiatów u genotypów odznaczających się wczesną porą kwitnienia. W okresie wiosennym 2019 roku odnotowano spadki temperatury (mierzone na wysokości $2 \mathrm{~m}$ nad powierzchnią gruntu) do $-1,2^{\circ} \mathrm{C} \mathrm{w}$ dniach 10-11 kwietnia, do $-3,6^{\circ} \mathrm{C}$ w dniach $15-16$ kwietnia oraz do $-1,7^{\circ} \mathrm{C}$ w dniu 8 maja. Do grupy najlepiej plonujących genotypów (powyżej $2 \mathrm{~kg}$ owoców z poletka) zaliczono T-201506-01 i T-201506-02 ('Alice' × 'Pink Rosa'), T-201510-02 i T-201510-04 ('Asia' × 'Matis'), T-201511-01 ('Asia' × 'Panvik'), T-201526-01, T-201526-02 i T-201526-05 ('Cigaline' × 'Grandarosa') oraz T-201536-06 ('Clery' × 'Grandarosa'). Dwie z wymienionych odmian ojcowskich, 'Grandarosa' i 'Pink Rosa', we wcześniejszych badaniach prowadzonych w Instytucie Ogrodnictwa w Skierniewicach odznaczały się wysoką plennością (Masny i Żurawicz, 2015; Masny i in., 2015). Jak wynika z przeprowadzonych wcześniej badań, odmiany te są nie tylko wysoce przydatne do uprawy towarowej, ale są również dobrymi donorami cechy wysokiej plenności, którą przekazują potomstwu.

Ocena fenotypowa cech jakości owoców badanych klonów (pomiar ich wielkości, a także ocena bonitacyjna atrakcyjności i jędrności) pozwoliła na wyodrębnienie najbardziej wartościowych genotypów. Do klonów o największych owocach zaliczono: T-201536-07 ('Clery' × 'Grandarosa'; średnia masa 1 owocu 21,0 g), T-201525-01 ('Cifrance' $\times$ 'Panvik'; 18,0 g) oraz T-201536-16 ('Clery' $\times$ 'Grandarosa'; 16,2 g). Najbardziej atrakcyjnymi owocami (ocena powyżej 4,5 w skali 1-5) w grupie badanych genotypów odznaczały się: T-201511-01 ('Asia' × 'Panvik'), T-201536-04 oraz T-201536-16 ('Clery' × 'Grandarosa'), zaś najbardziej jędrne owoce (ocena $5 \mathrm{w}$ skali 1-5) posiadały klony: T-201501-03 ('Alba' × 'Grandarosa'), T-201512-06 ('Camarosa' $\times$ 'Panvik'), T-201536-10 ('Clery' × 'Grandarosa'), T-201555-02 ('Marmolada' $\times$ 'Grandarosa') oraz T-201560-02 ('Onda' $\times$ 'Panvik'). Biorąc pod uwagę cały kompleks wymienionych cech jakości owoców, za najbardziej cenne uznano klony: T-201501-03 ('Alba' × 'Grandarosa'), T-201511-01 ('Asia' × 'Panvik'), T-20151205 i T-201512-06 ('Camarosa' $\times$ 'Panvik'), T-201514-04 ('Candiss' $\times$ 'Panvik'), T-20152606 ('Cigaline' $\times$ 'Grandarosa'), T-201536-01, T-201536-02, T-201536-05, T-201536-06, T-20153607 i T-201536-09 ('Clery' × 'Grandarosa') oraz T-201560-07 ('Onda' × 'Panvik').

Wymienione genotypy odznaczały się bardzo atrakcyjnymi owocami: dużymi lub bardzo dużymi, o stożkowatym lub sercowatym kształcie, pomarańczowoczerwonej lub intensywnie czerwonej barwie skórki $\mathrm{z}$ silnym połyskiem oraz wysokiej jędrności. Owoce o takich cechach są szczególnie pożądane przez konsumentów, dlatego też wysoka wizualna jakość owoców jest jednym z głównych kierunków prac hodowlanych prowadzonych na całym świecie (Roudeillac i Trajkovski, 2004), również w Instytucie Ogrodnictwa. 
Plon i wizualna jakość owoców 90 genotypów truskawki (Skierniewice, 2019)

Fruit yield and external fruit quality of 90 strawberry genotypes (Skierniewice, 2019)

\begin{tabular}{|c|c|c|c|c|c|}
\hline $\begin{array}{l}\text { Genotyp } \\
\text { Genotype }\end{array}$ & $\begin{array}{l}\text { Rodowód } \\
\text { Parentage }\end{array}$ & $\begin{array}{l}\text { Plon owoców } \\
\text { Fruit yield } \\
\text { (g) }\end{array}$ & $\begin{array}{l}\text { Masa } 1 \text { owocu } \\
\text { Weight of } 1 \\
\text { fruit } \\
(\mathrm{g})\end{array}$ & $\begin{array}{l}\text { Atrakcyjność } \\
\text { owoców }^{1} \\
\text { Fruit } \\
\text { attractiveness }^{1}\end{array}$ & $\begin{array}{c}\text { Jędrność } \\
\text { owoców }^{1} \\
\text { Fruit firmness }\end{array}$ \\
\hline T-201501-01 & Alba $\times$ Grandarosa & 1414 & 10,63 & 4,4 & 4,3 \\
\hline T-201501-02 & Alba $\times$ Grandarosa & 819 & 9,53 & 3,7 & 4,8 \\
\hline T-201501-03 & Alba $\times$ Grandarosa & 1494 & 8,81 & 4,2 & 5,0 \\
\hline T-201506-01 & Alice $\times$ Pink Rosa & 2094 & 11,44 & 3,6 & 4,3 \\
\hline T-201506-02 & Alice $\times$ Pink Rosa & 2334 & 10,14 & 3,5 & 4,5 \\
\hline T-201508-01 & Alice $\times$ Matis & 827 & 6,70 & 3,0 & 3,8 \\
\hline T-201508-02 & Alice $\times$ Matis & 832 & 7,46 & 2,8 & 4,8 \\
\hline T-201508-03 & Alice $\times$ Matis & 530 & 8,25 & 2,8 & 4,7 \\
\hline T-201508-04 & Alice $\times$ Matis & 1608 & 10,51 & 4,0 & 4,1 \\
\hline T-201510-01 & Asia $\times$ Matis & 771 & 7,02 & 3,9 & 4,9 \\
\hline T-201510-02 & Asia $\times$ Matis & 2737 & 11,49 & 3,9 & 4,9 \\
\hline T-201510-03 & Asia $\times$ Matis & 1860 & 8,01 & 4,3 & 4,4 \\
\hline T-201510-04 & Asia $\times$ Matis & 2744 & 8,18 & 4,1 & 4,8 \\
\hline T-201511-01 & Asia $\times$ Panvik & 2802 & 10,96 & 4,6 & 4,8 \\
\hline $\mathrm{T}-201512-01$ & Camarosa $\times$ Panvik & 617 & 7,90 & 3,6 & 4,3 \\
\hline T-201512-02 & Camarosa $\times$ Panvik & 1934 & 9,06 & 4,1 & 4,6 \\
\hline T-201512-03 & Camarosa $\times$ Panvik & 1934 & 10,61 & 3,5 & 4,8 \\
\hline T-201512-04 & Camarosa $\times$ Panvik & 1057 & 8,20 & 3,7 & 4,8 \\
\hline T-201512-05 & Camarosa $\times$ Panvik & 333 & 8,74 & 4,5 & 4,8 \\
\hline $\mathrm{T}-201512-06$ & Camarosa $\times$ Panvik & 1016 & 8,23 & 4,0 & 5,0 \\
\hline T-201513-01 & Candiss $\times$ Matis & 626 & 8,89 & 4,0 & 4,1 \\
\hline T-201513-02 & Candiss $\times$ Matis & 680 & 6,09 & 4,0 & 4,7 \\
\hline T-201513-03 & Candiss $\times$ Matis & 373 & 6,80 & 3,9 & 4,5 \\
\hline T-201513-04 & Candiss $\times$ Matis & 1060 & 7,59 & 3,9 & 4,8 \\
\hline T-201513-05 & Candiss $\times$ Matis & 1067 & 9,92 & 3,7 & 4,3 \\
\hline T-201513-06 & Candiss $\times$ Matis & 1145 & 9,89 & 4,0 & 4,4 \\
\hline T-201514-01 & Candiss $\times$ Panvik & 2000 & 10,74 & 4,2 & 4,6 \\
\hline T-201514-02 & Candiss $\times$ Panvik & 1987 & 9,27 & 3,3 & 4,3 \\
\hline T-201514-03 & Candiss $\times$ Panvik & 1569 & 7,00 & 4,1 & 4,4 \\
\hline T-201514-04 & Candiss $\times$ Panvik & 1784 & 11,62 & 4,3 & 4,7 \\
\hline T-201514-05 & Candiss $\times$ Panvik & 628 & 11,80 & 4,5 & 4,6 \\
\hline T-201514-06 & Candiss $\times$ Panvik & 692 & 9,73 & 4,3 & 4,8 \\
\hline T-201514-07 & Candiss $\times$ Panvik & 472 & 8,73 & 4,0 & 4,8 \\
\hline T-201514-08 & Candiss $\times$ Panvik & 536 & 7,70 & 3,6 & 4,1 \\
\hline T-201514-09 & Candiss $\times$ Panvik & 561 & 10,95 & 3,8 & 4,5 \\
\hline $\mathrm{T}-201517-01$ & Chandler $\times$ Matis & 734 & 10,65 & 3,9 & 4,5 \\
\hline T-201517-02 & Chandler $\times$ Matis & 672 & 8,71 & 4,1 & 4,6 \\
\hline $\mathrm{T}-201517-03$ & Chandler $\times$ Matis & 1251 & 10,32 & 4,4 & 4,6 \\
\hline $\mathrm{T}-201517-05$ & Chandler $\times$ Matis & 1282 & 5,39 & 3,3 & 4,8 \\
\hline T-201524-01 & Cifrance $\times$ Matis & 1333 & 8,05 & 4,1 & 4,7 \\
\hline
\end{tabular}

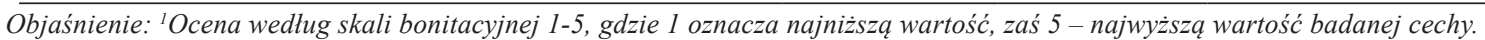

Explanation: ${ }^{1}$ Assessment according to the rating scale 1-5, where 1 is the lowest value and 5 - the highest value of the examined trait 
BIULETYN IHAR Nr 291 / 2020 Możliwości poprawy jakości owoców truskawki metodą hybrydyzacji wewnątrz- i międzygatunkowej...

Tabela 1 cd.

Table 1 cd.

Plon i wizualna jakość owoców 90 genotypów truskawki (Skierniewice, 2019)

Fruit yield and external fruit quality of 90 strawberry genotypes (Skierniewice, 2019)

\begin{tabular}{|c|c|c|c|c|c|}
\hline $\begin{array}{l}\text { Genotyp } \\
\text { Genotype }\end{array}$ & $\begin{array}{l}\text { Rodowód } \\
\text { Parentage }\end{array}$ & $\begin{array}{l}\text { Plon owoców } \\
\text { Fruit yield } \\
\text { (g) }\end{array}$ & $\begin{array}{l}\text { Masa } 1 \text { owocu } \\
\text { Weight of } 1 \\
\text { fruit } \\
\text { (g) }\end{array}$ & $\begin{array}{l}\text { Atrakcyjność } \\
\text { owoców }^{1} \\
\text { Fruit } \\
\text { attractiveness }^{1}\end{array}$ & $\begin{array}{c}\text { Jędrność } \\
\text { owoców }^{1} \\
\text { Fruit firmness }\end{array}$ \\
\hline T-201524-02 & Cifrance $\times$ Matis & 916 & 9,59 & 4,0 & 4,6 \\
\hline $\mathrm{T}-201525-01$ & Cifrance $\times$ Panvik & 821 & 17,97 & 3,3 & 4,5 \\
\hline $\mathrm{T}-201526-01$ & Cigaline $\times$ Grandarosa & 2294 & 8,10 & 4,1 & 4,9 \\
\hline $\mathrm{T}-201526-02$ & Cigaline $\times$ Grandarosa & 2618 & 10,97 & 3,7 & 4,7 \\
\hline $\mathrm{T}-201526-03$ & Cigaline $\times$ Grandarosa & 1010 & 7,59 & 3,6 & 4,6 \\
\hline T-201526-04 & Cigaline $\times$ Grandarosa & 1374 & 8,07 & 3,9 & 4,6 \\
\hline $\mathrm{T}-201526-05$ & Cigaline $\times$ Grandarosa & 2143 & 7,70 & 4,0 & 4,5 \\
\hline $\mathrm{T}-201526-06$ & Cigaline $\times$ Grandarosa & 840 & 9,96 & 4,5 & 4,7 \\
\hline T-201529-01 & Cigaline $\times$ Matis & 476 & 10,08 & 4,0 & 4,0 \\
\hline T-201536-01 & Clery $\times$ Grandarosa & 1103 & 9,08 & 4,2 & 4,8 \\
\hline T-201536-02 & Clery $\times$ Grandarosa & 1033 & 9,03 & 4,5 & 4,9 \\
\hline $\mathrm{T}-201536-03$ & Clery $\times$ Grandarosa & 1208 & 7,13 & 4,3 & 4,8 \\
\hline T-201536-04 & Clery $\times$ Grandarosa & 671 & 10,81 & 4,6 & 4,6 \\
\hline $\mathrm{T}-201536-05$ & Clery $\times$ Grandarosa & 997 & 9,44 & 4,3 & 4,7 \\
\hline T-201536-06 & Clery $\times$ Grandarosa & 2791 & 10,44 & 4,4 & 4,7 \\
\hline $\mathrm{T}-201536-07$ & Clery $\times$ Grandarosa & 218 & 20,96 & 4,5 & 4,9 \\
\hline T-201536-08 & Clery $\times$ Grandarosa & 362 & 11,37 & 4,5 & 4,5 \\
\hline T-201536-09 & Clery $\times$ Grandarosa & 633 & 9,22 & 4,0 & 4,9 \\
\hline $\mathrm{T}-201536-10$ & Clery $\times$ Grandarosa & 489 & 11,76 & 4,0 & 5,0 \\
\hline $\mathrm{T}-201536-14$ & Clery $\times$ Grandarosa & 187 & 6,74 & 3,8 & 4,8 \\
\hline $\mathrm{T}-201536-15$ & Clery $\times$ Grandarosa & 202 & 7,35 & 3,8 & 4,5 \\
\hline $\mathrm{T}-201536-16$ & Clery $\times$ Grandarosa & 744 & 16,12 & 4,9 & 4,6 \\
\hline $\mathrm{T}-201536-17$ & Clery $\times$ Grandarosa & 241 & 14,92 & 3,8 & 4,0 \\
\hline $\mathrm{T}-201537-01$ & Clery $\times$ Matis & 226 & 10,23 & 3,5 & 4,2 \\
\hline $\mathrm{T}-201537-02$ & Clery $\times$ Matis & 1031 & 9,16 & 4,0 & 4,3 \\
\hline T-201539-01 & Darselect $\times$ Grandarosa & 920 & 6,27 & 3,3 & 3,5 \\
\hline $\mathrm{T}-201555-01$ & Marmolada $\times$ Grandarosa & 1170 & 8,18 & 3,0 & 4,3 \\
\hline $\mathrm{T}-201555-02$ & Marmolada $\times$ Grandarosa & 996 & 8,79 & 3,3 & 5,0 \\
\hline $\mathrm{T}-201555-04$ & Marmolada $\times$ Grandarosa & 952 & 7,83 & 4,3 & 4,4 \\
\hline $\mathrm{T}-201555-06$ & Marmolada $\times$ Grandarosa & 1241 & 7,43 & 3,8 & 4,8 \\
\hline $\mathrm{T}-201555-07$ & Marmolada $\times$ Grandarosa & 104 & 11,00 & 4,0 & 4,8 \\
\hline $\mathrm{T}-201555-08$ & Marmolada $\times$ Grandarosa & 833 & 7,92 & 3,6 & 4,9 \\
\hline $\mathrm{T}-201555-09$ & Marmolada $\times$ Grandarosa & 675 & 10,33 & 3,7 & 4,7 \\
\hline $\mathrm{T}-201560-01$ & Onda $\times$ Panvik & 629 & 6,29 & 3,8 & 4,5 \\
\hline T-201560-02 & Onda $\times$ Panvik & 397 & 5,79 & 4,0 & 5,0 \\
\hline T-201560-04 & Onda $\times$ Panvik & 519 & 7,37 & 3,8 & 4,3 \\
\hline $\mathrm{T}-201560-05$ & Onda $\times$ Panvik & 244 & 5,71 & 3,3 & 4,7 \\
\hline $\mathrm{T}-201560-07$ & Onda $\times$ Panvik & 1563 & 11,44 & 4,2 & 4,8 \\
\hline $\mathrm{T}-201560-08$ & Onda $\times$ Panvik & 1167 & 11,61 & 3,8 & 4,9 \\
\hline $\mathrm{T}-201567-01$ & Patty $\times$ Panvik & 876 & 6,86 & 3,9 & 4,9 \\
\hline
\end{tabular}

Objaśnienie: ${ }^{1}$ Ocena według skali bonitacyjnej 1-5, gdzie 1 oznacza najniższa wartość, zaś 5 - najwyższą wartość badanej cechy.

Explanation: ${ }^{1}$ Assessment according to the rating scale 1-5, where 1 is the lowest value and 5 - the highest value of the examined trait 
Plon i wizualna jakość owoców 90 genotypów truskawki (Skierniewice, 2019)

Fruit yield and external fruit quality of 90 strawberry genotypes (Skierniewice, 2019)

\begin{tabular}{|c|c|c|c|c|c|}
\hline $\begin{array}{l}\text { Genotyp } \\
\text { Genotype }\end{array}$ & $\begin{array}{l}\text { Rodowód } \\
\text { Parentage }\end{array}$ & $\begin{array}{l}\text { Plon owoców } \\
\text { Fruit yield } \\
\text { (g) }\end{array}$ & $\begin{array}{l}\text { Masa } 1 \text { owocu } \\
\text { Weight of } 1 \\
\text { fruit } \\
\text { (g) }\end{array}$ & $\begin{array}{l}\text { Atrakcyjność } \\
\text { owoców }^{1} \\
\text { Fruit } \\
\text { attractiveness }^{1}\end{array}$ & $\begin{array}{c}\text { Jędrność } \\
\text { owoców }^{1} \\
\text { Fruit firmness }\end{array}$ \\
\hline T-201567-02 & Patty $\times$ Panvik & 307 & 11,80 & 3,9 & 4,6 \\
\hline T-201567-03 & Patty $\times$ Panvik & 1070 & 8,27 & 4,1 & 4,8 \\
\hline T-201567-04 & Patty $\times$ Panvik & 1173 & 7,98 & 4,1 & 4,3 \\
\hline T-201571-01 & Sophie $\times$ Pink Rosa & 509 & 8,70 & 4,0 & 4,5 \\
\hline T-201571-02 & Sophie $\times$ Pink Rosa & 210 & 4,62 & 3,3 & 4,3 \\
\hline T-201571-03 & Sophie $\times$ Pink Rosa & 725 & 8,78 & 3,4 & 4,6 \\
\hline T-201580-01 & F. chil. Del Norte $\times$ Elsanta & 1046 & 3,56 & 3,2 & 4,3 \\
\hline T-201580-02 & F. chil. Del Norte $\times$ Elsanta & 649 & 3,61 & 2,8 & 4,3 \\
\hline T-201585-01 & F. chil. Yaquina A $\times$ Matis & 335 & 4,53 & 3,7 & 4,5 \\
\hline T-201590-01 & F. chil. Yaquina B $\times$ Panvik & 1408 & 4,49 & 2,7 & 4,3 \\
\hline \multicolumn{2}{|c|}{$\begin{array}{l}\text { Średnia dla wszystkich genotypów } \\
\text { Average for all genotypes }\end{array}$} & 1051 & 9,05 & 3,87 & 4,58 \\
\hline
\end{tabular}

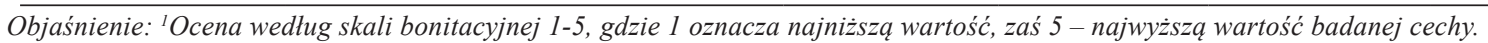
Explanation: ' Assessment according to the rating scale 1-5, where 1 is the lowest value and 5 - the highest value of the examined trait

Zawartość ekstraktu refraktometrycznego (substancji rozpuszczalnych) w owocach 90 badanych genotypów wahała się od 5,3\% do 12,7\% (Tab. 2). Najwyższą zawartość ekstraktu (powyżej 11\%) wykazano w owocach klonów: T-201508-03 ('Alice' $\times$ 'Matis'), T-201517-05 ('Chandler' $\times$ 'Matis'), T-201536-09 i T-201536-16 ('Clery' × 'Grandarosa'), T-201567-01 i T-201567-04 ('Patty' × 'Panvik') oraz T-201580-01 (F. chiloensis Del Norte $\times$ 'Elsanta'). Należy podkreślić, że owoce tych klonów w naszych badaniach zawierają więcej cukrów rozpuszczalnych w porównaniu z ocenianymi przez Hasinga i współautorów (2013) owocami mieszańców, otrzymanych w wyniku czynnikowego układu krzyżowań $(5 \times 4)$, w których stwierdzono zawartość ekstraktu na poziomie $5,1 \%$ do $9,9 \%$ oraz $6,5 \%$ do $10,6 \%$, zależnie od sezonu. Podobnie Voća i in. (2008), badając skład chemiczny owoców siedmiu odmian truskawki ('Clery', 'Maya', 'Alba', 'Miss', 'Camarosa', 'Queen Elisa' i 'Elsanta'), wykazali zawartość substancji rozpuszczalnych na poziomie od $6 \%$ dla odmiany 'Maya' do $10,1 \%$ dla odmiany 'Elsanta'. Poziom cukrów rozpuszczalnych w owocach truskawki, przede wszystkim sacharozy, glukozy i fruktozy, jest ważną cechą jakościową, decydującą o ich smaku (Cordenunsi i in., 2002; Perkins-Veazie, 1995).

Zawartość kwasu askorbinowego w owocach badanych klonów wahała się od 24 do $106 \mathrm{mg} / 100 \mathrm{~g}$. Tak duże zróżnicowanie tej cechy jest typowe pomiędzy odmianami uprawnymi truskawki (da Silva -Pinto i in., 2008; van De Velde i in., 2013). Jednak z punktu widzenia zdrowia ludzkiego najcenniejsze są owoce o wysokiej zawartości kwasu askorbinowego (Cruz-Rus i in., 2011). W naszych badaniach najwyższym poziomem kwasu askorbinowego w owocach (powyżej $90 \mathrm{mg} / 100 \mathrm{~g}$ ) odznaczały się klony: T-201501-03 ('Alba' × 'Grandarosa'), T-201526-02 i T-201526-05 ('Cigaline' $\times$ 'Grandarosa'), T-201536-08 i T-201536-15 ('Clery' × 'Grandarosa'), T-201537-02 ('Clery' $\times$ 'Matis'), T-201539-01 ('Darselect' $\times$ 'Grandarosa'), T-201555-02, T-20155508 i T-201555-09 ('Marmolada' × 'Grandarosa') oraz T-201567-01 i T-201567-03 ('Patty' × 'Panvik'). Zawartość tego składnika w owocach wymienionych klonów jest zatem znacznie wyższa od przeciętnej, wynoszącej około $60 \mathrm{mg} / 100 \mathrm{~g}$ świeżych owoców (Miller i in., 2019). Według Cruz-Rus i współautorów (2011), jeszcze niższą zawartością kwasu askorbinowego $(50 \mathrm{mg} / 100 \mathrm{~g})$ charakteryzują się owoce odmiany 'Camarosa', będącej formą mateczną sześciu, spośród 90 genotypów opisywanych w niniejszej pracy.

Zawartość antocyjanów w owocach wszystkich badanych klonów wahała się od 8 do $70 \mathrm{mg} / 100 \mathrm{~g}$. Należy podkreślić, że bardzo wysoka zawartość antocyjanów w spożywanych owocach jest pożądana $\mathrm{z}$ uwagi na silne właściwości przeciwutleniające tych związków. W naszych badaniach zawartość antocyjanów przekraczająca $50 \mathrm{mg} / 100 \mathrm{~g}$ owoców, stwierdzona została w owocach klonów T-20150801 ('Alice' × 'Matis'), T-201512-03 ('Camarosa' × 'Panvik'), T-201514-02 i T-201514-08 ('Candiss' $\times$ 'Panvik'), T-201517-05 ('Chandler' $\times$ 'Matis'), 
T-201567-04 ('Patty' × 'Panvik') oraz T-201580-01 (Fragaria chiloensis Del Norte $\times$ 'Elsanta'). Świadczy to o wysokiej wartości prozdrowotnej owoców wymienionych klonów. Według Voća i współautorów (2008), najmniej antocyjanów (spośród siedmiu badanych przez nich odmian truskawki) zawierały owoce odmiany 'Elsanta' $(114,76 \mathrm{mg} / \mathrm{kg})$, podczas gdy najwyższą zawartością tych związków odznaczała się odmiana 'Camarosa' $(327,39 \mathrm{mg} / \mathrm{kg})$, będąca formą mateczną jednego $\mathrm{z}$ wymienionych wyżej mieszańców. Na bardzo wysoką zawartość antocyjanów w owocach odmiany 'Camarosa' $(840,2 \mathrm{mg} / \mathrm{kg})$, zwrócili również uwagę Garcia-Viguera i współautorzy (1998).

Zawartość związków fenolowych w owocach badanych genotypów wynosiła od 257 do 478 $\mathrm{mg} / 100 \mathrm{~g}$ świeżych owoców. Najwyższym poziomem związków fenolowych w owocach (powyżej $430 \mathrm{mg} / 100 \mathrm{~g}$ ) wyróżniały się genotypy: T-201501-02 i T-201501-03 ('Alba' × 'Grandarosa'), T-201512-04 i T-201512-05 ('Camarosa' $\times$ 'Panvik'), T-20156701, T-201567-02 i T-201567-04 ('Patty' × 'Panvik') oraz T-201585-01 (Fragaria chiloensis Yaquina A $\times$ 'Matis'). Tak wysokiego poziomu związków fenolowych wymaga się zwłaszcza od owoców, przeznaczonych na rynek owoców deserowych, ze względu na ich wysoką wartość prozdrowotną. Jednakże, mimo ogromnego znaczenia polifenoli dla diety człowieka, nadmierny poziom tych związków może powodować lekko cierpki smak truskawek i przez to obniżać ich wartość sensoryczną. Z kolei dla owoców przeznaczonych do przetwórstwa, wysoki poziom związków fenolowych może wiązać się z szeregiem problemów technologicznych, a więc najlepsze do tego celu są owoce o średniej zawartości tych związków, która w przypadku badanych klonów wynosiła $360 \mathrm{mg} / 100 \mathrm{~g}$ świeżych owoców. W badaniach, przeprowadzonych przez Palmieri i in. (2017), zawartość fenoli w dojrzałych truskawkach także była zależna od odmiany i wynosiła od 33,2 mg/100 g świeżych owoców dla odmiany 'Marmolada' do 127,3 mg/100 g dla odmiany 'Eva', a więc znacznie mniej w porównaniu z klonami wyhodowanymi w Instytucie Ogrodnictwa.

Biorąc pod uwagę kompleks analizowanych składników bioaktywnych, za szczególnie cenne klony uznano T-201510-02 ('Asia' × 'Matis'), T-201514-02 i T-201514-08 ('Candiss' $\times$ 'Panvik'), T-201517-05 ('Chandler' $\times$ 'Matis'), T-20152601 i T-201526-04 ('Cigaline' $\times$ 'Grandarosa'), T-201567-03 i T-201567-04 ('Patty' × 'Panvik') oraz T-201571-02 ('Sophie' × 'Pink Rosa'), ze względu na wysoką zawartość w owocach związków fenolowych ogółem, antocyjanów, a także kwasu askorbinowego. Ponadto, z uwagi na fakt, że związki fenolowe oddziaływają synergistycznie na organizm człowieka wraz z kwasem L-askorbinowym (Kazimierczak i in., 2009), do wartościowych genotypów zaliczono także klony T-201501-02 i T-201501-03 ('Alba' × 'Grandarosa'), T-201526-05 i T-201526-06 ('Cigaline' $\times$ 'Grandarosa'), T-201536-04, T-201536-05, T-201536-06, T-201536-14, T-201536-15 i T-20153616 ('Clery' × 'Grandarosa') oraz T-201571-02 ('Sophie' $\times$ 'Pink Rosa'), posiadające owoce o wysokiej zawartości obu tych składników. Należy także podkreślić, że cztery z wymienionych klonów (T-201501-03, T-201526-06, T-201536-05, T-201536-06) odznaczały się również wysoką jakością zewnętrzną owoców. Można zatem oczekiwać, że owoce tych klonów będą szczególnie cenione przez konsumentów ze względu na ich wysokie walory jakościowe i prozdrowotne. Klony te moga w przyszłości dać początek nowym, cennym odmianom, jeżeli potwierdzą swoje inne walory produkcyjne, w tym odporność lub małą wrażliwość roślin na stresy biotyczne i abiotyczne.

Skład chemiczny owoców 90 genotypów truskawki (Skierniewice, 2019)

Chemical composition of fruit of 90 strawberry genotypes (Skierniewice, 2019)

\begin{tabular}{|c|c|c|c|c|}
\hline $\begin{array}{l}\text { Genotyp } \\
\text { Genotype }\end{array}$ & $\begin{array}{c}\text { Ekstrakt } \\
\text { Extract } \\
{[\%]}\end{array}$ & $\begin{array}{l}\text { Zawartość związków } \\
\text { fenolowych } \\
\text { Content of phenolic } \\
\text { compounds } \\
{[\mathrm{mg} / 100 \mathrm{~g}]}\end{array}$ & $\begin{array}{c}\text { Zawartość antocyjanów } \\
\text { Content of anthocyanins } \\
{[\mathrm{mg} / 100 \mathrm{~g}]}\end{array}$ & $\begin{array}{c}\text { Zawartość kwasu } \\
\text { L-askorbinowego } \\
\text { Content of L-ascorbic acid } \\
{[\mathrm{mg} / 100 \mathrm{~g}]}\end{array}$ \\
\hline T-201501-01 & 9,0 & 306 & 20 & 73 \\
\hline T-201501-02 & 9,3 & 478 & 20 & 89 \\
\hline T-201501-03 & 8,8 & 434 & 18 & 103 \\
\hline T-201506-01 & 7,9 & 265 & 42 & 52 \\
\hline T-201506-02 & 7,2 & 369 & 48 & 26 \\
\hline T-201508-01 & 9,0 & 322 & 54 & 39 \\
\hline T-201508-02 & 8,6 & 337 & 48 & 32 \\
\hline
\end{tabular}


Tabela 2 cd.

Table 2 cd.

Skład chemiczny owoców 90 genotypów truskawki (Skierniewice, 2019)

Chemical composition of fruit of 90 strawberry genotypes (Skierniewice, 2019)

\begin{tabular}{|c|c|c|c|c|}
\hline $\begin{array}{l}\text { Genotyp } \\
\text { Genotype }\end{array}$ & $\begin{array}{c}\text { Ekstrakt } \\
\text { Extract } \\
{[\%]}\end{array}$ & $\begin{array}{l}\text { Zawartość związków } \\
\text { fenolowych } \\
\text { Content of phenolic } \\
\text { compounds } \\
{[\mathrm{mg} / 100 \mathrm{~g}]}\end{array}$ & $\begin{array}{c}\text { Zawartość antocyjanów } \\
\text { Content of anthocyanins } \\
{[\mathrm{mg} / 100 \mathrm{~g}]}\end{array}$ & $\begin{array}{c}\text { Zawartość kwasu } \\
\text { L-askorbinowego } \\
\text { Content of L-ascorbic acid } \\
{[\mathrm{mg} / 100 \mathrm{~g}]}\end{array}$ \\
\hline T-201508-03 & 11,1 & 366 & 34 & 61 \\
\hline T-201508-04 & 8,9 & 291 & 39 & 60 \\
\hline T-201510-01 & 8,8 & 303 & 26 & 74 \\
\hline T-201510-02 & 8,7 & 372 & 50 & 71 \\
\hline T-201510-03 & 9,3 & 360 & 37 & 66 \\
\hline T-201510-04 & 7,2 & 298 & 31 & 41 \\
\hline T-201511-01 & 9,3 & 325 & 20 & 69 \\
\hline T-201512-01 & 9,0 & 383 & 35 & 44 \\
\hline T-201512-02 & 9,0 & 362 & 33 & 50 \\
\hline T-201512-03 & 7,5 & 391 & 55 & 58 \\
\hline T-201512-04 & 9,9 & 452 & 36 & 52 \\
\hline T-201512-05 & 10,2 & 433 & 46 & 45 \\
\hline T-201512-06 & 10,0 & 388 & 43 & 56 \\
\hline T-201513-01 & 9,8 & 348 & 24 & 39 \\
\hline T-201513-02 & 10,1 & 421 & 50 & 59 \\
\hline $\mathrm{T}-201513-03$ & 9,6 & 358 & 38 & 54 \\
\hline T-201513-04 & 9,1 & 390 & 26 & 53 \\
\hline T-201513-05 & 8,6 & 392 & 41 & 46 \\
\hline T-201513-06 & 9,6 & 422 & 40 & 59 \\
\hline T-201514-01 & 8,0 & 304 & 27 & 61 \\
\hline T-201514-02 & 9,3 & 394 & 65 & 75 \\
\hline T-201514-03 & 9,1 & 322 & 33 & 71 \\
\hline T-201514-04 & 9,1 & 367 & 34 & 52 \\
\hline T-201514-05 & 11,0 & 356 & 41 & 75 \\
\hline T-201514-06 & 10,0 & 301 & 36 & 67 \\
\hline T-201514-07 & 9,2 & 321 & 23 & 61 \\
\hline T-201514-08 & 10,5 & 403 & 70 & 70 \\
\hline T-201514-09 & 10,1 & 397 & 40 & 65 \\
\hline T-201517-01 & 8,0 & 381 & 36 & 54 \\
\hline T-201517-02 & 8,6 & 328 & 32 & 55 \\
\hline T-201517-03 & 9,4 & 359 & 44 & 59 \\
\hline T-201517-05 & 11,2 & 390 & 54 & 81 \\
\hline T-201524-01 & 5,3 & 318 & 21 & 25 \\
\hline T-201524-02 & 10,5 & 344 & 37 & 84 \\
\hline T-201525-01 & 9,6 & 326 & 34 & 61 \\
\hline $\mathrm{T}-201526-01$ & 7,8 & 407 & 33 & 83 \\
\hline T-201526-02 & 9,0 & 351 & 26 & 98 \\
\hline T-201526-03 & 10,0 & 319 & 23 & 83 \\
\hline T-201526-04 & 9,7 & 392 & 34 & 88 \\
\hline T-201526-05 & 9,9 & 422 & 28 & 106 \\
\hline T-201526-06 & 9,1 & 377 & 25 & 80 \\
\hline T-201529-01 & 9,3 & 344 & 24 & 88 \\
\hline T-201536-01 & 9,4 & 306 & 31 & 85 \\
\hline T-201536-02 & 9,4 & 347 & 20 & 87 \\
\hline T-201536-03 & 9,1 & 313 & 25 & 75 \\
\hline T-201536-04 & 8,6 & 385 & 21 & 73 \\
\hline T-201536-05 & 10,5 & 368 & 19 & 78 \\
\hline T-201536-06 & 9,4 & 385 & 23 & 74 \\
\hline T-201536-07 & 8,3 & 320 & 39 & 65 \\
\hline T-201536-08 & 8,8 & 340 & 22 & 98 \\
\hline T-201536-09 & 11,6 & 280 & 12 & 86 \\
\hline T-201536-10 & 10,5 & 325 & 20 & 76 \\
\hline T-201536-14 & 10,2 & 427 & 24 & 60 \\
\hline
\end{tabular}


BIULETYN IHAR Nr 291 / 2020

Możliwości poprawy jakości owoców truskawki metodą hybrydyzacji wewnątrz- i międzygatunkowej...

Tabela 2 cd.

Table 2 cd.

Skład chemiczny owoców 90 genotypów truskawki (Skierniewice, 2019)

Chemical composition of fruit of 90 strawberry genotypes (Skierniewice, 2019)

\begin{tabular}{|c|c|c|c|c|}
\hline $\begin{array}{l}\text { Genotyp } \\
\text { Genotype }\end{array}$ & $\begin{array}{c}\text { Ekstrakt } \\
\text { Extract } \\
{[\%]}\end{array}$ & $\begin{array}{l}\text { Zawartość związków } \\
\text { fenolowych } \\
\text { Content of phenolic } \\
\text { compounds } \\
{[\mathrm{mg} / 100 \mathrm{~g}]}\end{array}$ & $\begin{array}{c}\text { Zawartość antocyjanów } \\
\text { Content of anthocyanins } \\
{[\mathrm{mg} / 100 \mathrm{~g}]}\end{array}$ & $\begin{array}{c}\text { Zawartość kwasu } \\
\text { L-askorbinowego } \\
\text { Content of L-ascorbic acid } \\
{[\mathrm{mg} / 100 \mathrm{~g}]}\end{array}$ \\
\hline T-201536-15 & 11,0 & 373 & 30 & 102 \\
\hline T-201536-16 & 11,8 & 418 & 22 & 83 \\
\hline T-201536-17 & 7,0 & 341 & 27 & 33 \\
\hline $\mathrm{T}-201537-01$ & 6,0 & 295 & 22 & 24 \\
\hline T-201537-02 & 10,9 & 354 & 27 & 98 \\
\hline T-201539-01 & 10,3 & 354 & 27 & 91 \\
\hline T-201555-01 & 10,0 & 258 & 35 & 73 \\
\hline T-201555-02 & 9,7 & 257 & 32 & 98 \\
\hline T-201555-04 & 9,5 & 318 & 27 & 57 \\
\hline T-201555-06 & 9,0 & 367 & 24 & 54 \\
\hline T-201555-07 & 6,6 & 333 & 25 & 27 \\
\hline T-201555-08 & 8,5 & 335 & 25 & 94 \\
\hline T-201555-09 & 8,1 & 340 & 16 & 97 \\
\hline T-201560-01 & 6,3 & 309 & 9 & 47 \\
\hline T-201560-02 & 8,2 & 367 & 29 & 46 \\
\hline T-201560-04 & 10,1 & 366 & 27 & 73 \\
\hline T-201560-05 & 7,1 & 281 & 35 & 46 \\
\hline T-201560-07 & 9,5 & 327 & 18 & 49 \\
\hline T-201560-08 & 8,7 & 345 & 27 & 62 \\
\hline $\mathrm{T}-201567-01$ & 11,2 & 454 & 8 & 102 \\
\hline T-201567-02 & 10,7 & 442 & 33 & 64 \\
\hline T-201567-03 & 10,1 & 386 & 34 & 98 \\
\hline T-201567-04 & 12,7 & 442 & 52 & 80 \\
\hline T-201571-01 & 8,2 & 419 & 24 & 76 \\
\hline T-201571-02 & 11,0 & 419 & 33 & 74 \\
\hline T-201571-03 & 10,0 & 332 & 28 & 65 \\
\hline T-201580-01 & 11,1 & 367 & 54 & 57 \\
\hline T-201580-02 & 10,0 & 314 & 43 & 59 \\
\hline T-201585-01 & 8,8 & 435 & 34 & 44 \\
\hline T-201590-01 & 10,9 & 416 & 18 & 45 \\
\hline $\begin{array}{l}\text { Średnia dla wszystkich } \\
\text { genotypów } \\
\text { Average for all genotypes }\end{array}$ & 9,31 & 359,5 & 31,9 & 66,5 \\
\hline
\end{tabular}

\section{Wnioski}

1. Możliwe jest poprawienie zewnętrznej jakości owoców truskawki oraz zwiększenie w nich zawartości składników bioaktywnych metodą hodowli konwencjonalnej opartej na hybrydyzacji wewnątrz- i międzygatunkowej w obrębie rodzaju Fragaria.

2. Szczególne cenne dla diety człowieka są owoce klonów T-201510-02 ('Asia' × 'Matis'), T-201514-02 i T-201514-08 ('Candiss' × 'Panvik'), T-201517-05 ('Chandler' $\times$ 'Matis'), T-20152601 i T-201526-04 ('Cigaline' $\times$ 'Grandarosa'), T-201567-03 i T-201567-04 ('Patty' × 'Panvik') oraz T-201571-02 ('Sophie' × 'Pink Rosa'), ze względu na wysoką zawartość takich związków bioaktywnych, jak związki polifenolowe, antocyjany, a także kwas askorbinowy.

3. Genotypy o wysokiej jakości zewnętrznej i wewnętrznej owoców mogą stać się w przyszłości cennymi odmianami uprawnymi lub być wykorzystane w dalszych pracach hodowlanych jako źródło genów warunkujących te cechy.

Badania finansowano ześrodków projektu MRiRW: Badania podstawowe na rzecz postepu biologicznego w produkcji roślinnej, decyzja HOR. hn.802.4.2019 z dnia 14.05.2019 r., Zadanie nr 76. 


\section{Literatura}

Battino, M., Beekwilder, J., Denoyes-Rothan, B., Laimer, M., McDougall, G.J., Mezzetti, B. (2009). Bioactive compounds in berries relevant to human health. Nutrition Reviews 67 (1): 145-150.

Battino, M., Forbez-Hernandez, T. Y., Gasparrini, M., Afrin, S., Mezzetti, B., Giampieri, F. (2017). The effects of strawberry bioactive compounds on human health. Acta Hort. (ISHS) (1156): 355-362. https://doi.org?10.17660/ ActaHortic.2017.1156.54

Bialasiewicz, P., Prymont-Przyminska, A., Zwolinska, A., Sarniak, A., Wlodarczyk, A., Krol, M., Glusac, J., Nowak, P., Markowski, J., Rutkowski KP., Nowak, D. (2014). Addition of strawberries to the usual diet decreases resting chemiluminescence of fasting blood in healthy subjects-possible health-promoting effect of these fruits consumption. Journal of the American College of Nutrition 33 (4): 274-87.

Capocasa, F., Diamanti, J., Tulipani, S., Battino, M., Mezzetti, B. (2008) a. Breeding strawberry (Fragaria $\times$ ananassa Duch.) to increase fruit nutritional quality. Biofactors 34 (1): 67-72.

Capocasa, F., Scalzo, J., Mezzetti, B., Battino, M., 2008 b. Combining quality and antioxidant attributes in the strawberry: The role of genotype. Food Chemistry 111: 872-878.

Cordenunsi, B. R., Oliveira Do Nascimento, J. R., Genovese, M. I., Lajolo, F. M. (2002). Influence of cultivar on quality parameters and chemical composition of strawberry fruits grown in Brazil. J. Agric. Food Chem. 50: 2581-2586.

Cruz-Rus, E., Amaya, I., Sanchez-Sevilla, J. F., Botella, M. A., Valpuesta, V., 2011. Regulation of L-ascorbic acid content in strawberry fruits. J. Exp. Bot. 62 (12): 4191-4201.

Da Silva-Pinto, M., Lajolo, F. M., Genovese, M. I. (2008). Bioactive compounds and quantification of total ellagic acid in strawberries (Fragaria $\times$ ananassa Duch.). Food Chemistry 107: 1629-1635.

Diamanti, J., Capocasa, F., Balducci, F., Battino, M., Hancock, J., Mezzetti, B. (2012). Increasing strawberry fruit sensorial and nutritional quality using wild and cultivated germplasm. PLoS ONE 7 (10): e46470. DOI: 10.1371/ journal.pone. 0046470

EUBerry germplasm database (2014).http://www.euberry. univpm.it/sites/www.euberry.univpm.it/files/euberry/ documenti/D1.1\%20Data\%20base/Revisione/Summary-Genotype \%20characteristics\%20-\%20WP1\%20 7_2_14\%20last\%20versionStrawberry.pdf

Garcia-Viguera, C., Zafrilla, P., Tomás-Barberán, F. A. (1998). The use of acetone as an extactionsolvent for anthocysanins from strawberry fruit. Phytochem. Anal. 9: 274-277.

Giampieri, F., Tulipani, S., Alvarez-Suarez, J. M., Quiles, J. L., Mezzetti, B., Battino, M., 2012. The strawberry: Composition, nutritional quality and impact on human health. Nutrition 28: 9-19.
Giusti, M. M., Wrolstad, R. E. (2001). Characterization and Measurement of Anthocyanins by UV-Visible Spectroscopy. In: Current Protocols in Food Analytical Chemistry (John Wiley \& Sons, Inc., August 2001): F1.2.1-F1.2.13. DOI: 10.1002/0471142913.faf0102s00

Hasing, T. N., Osorio, L. F., Whitaker, V. M. (2013). Withinseason stability of strawberry soluble solids content. J. Amer. Soc. Hort. Sci. 138 (3): 190-197.

Kazimierczak, R., Hallmann, E., Brodzka, A., Rembiałkowska, E. (2009). A comparison of the polyphenol and vitamin C content in jams of several varieties of black currants Ribes nigrum L. from the organic and conventional cultivation. Journal of Research and Applications in Agricultural Engineering 54 (3): 123-130.

Marques, K. K., Renfroe, M. H., Bowling, B. Brevard, P., Lee, R. E., Gloeckner, J. W. (2010). Differences in antioxidant levels of fresh, frozen and freeze-dried strawberries and strawberry jam. International Journal of Food Science and Nutrition 61 (8): 759-769.

Masny, A., Żurawicz, E. (2015). 'Pink Rosa’ Strawberry. HortScience 50 (10): 1585-1587.

Masny, A., Żurawicz, E., Markowski, J. (2015). 'Grandarosa' Strawberry. HortScience 50 (9): 1401-1404.

Michalska, A., Carlen, C., Heritier, J., Andlauer, W. (2017). Profiles of bioactive compounds in fruits and leaves of strawberry cultivars. Journal of Berry Research 7 (2): 71-84.

Miller, K., Feucht, W., Schmid, M. (2019). Bioactive compounds of strawberry and blueberry and their potential health effects based on human intervention studies: a brief overview. Nutrients, 11, 1510. DOI: 10.3390/nu11071510

Mirończuk-Chodakowska, I., Zujko, M. E., Witkowska, A. (2011). Zawartość polifenoli oraz aktywność antyoksydacyjna niektórych przetworów owocowych o znacznym stopniu przetworzenia. Bromat. Chem. Toksykol. XLIV (3): 905-910.

Palmieri, L., Masuero, D., Martinatti, P., Baratto, G., Martens, S., Vrhovsek, U. (2017). Genotype-by-environment effect on bioactive compounds in strawberry (Fragaria $\times$ ananassa Duch.). J. Sci. Food Agric. 97: 4180-4189. DOI: $10.1002 /$ jsfa. 8290

Perkins-Veazie, P. (1995). Growth and ripening of strawberry fruit. Hort. Rev. 17: 267-297.

Prymont-Przymińska, A., Białasiewicz, P., Zwolińska, A., Sarniak, A., Włodarczyk, A., Markowski, J., Rutkowski, K. P., Nowak, D. (2016). Addition of strawberries to the usual diet increases postprandial but not fasting non urate plasma antioxidant activity in healthy subjects. Journal of Clinical Biochemistry and Nutrition, 59 (2): $1-8$.

Roudeillac, P., Trajkovski, K. (2004). Breeding for fruit quality and nutrition in strawberries. Acta Horticulturae 649: $55-60$. 
Tsao, R., Yang, R. (2003) Optimization of a new mobile phase to know the complex and real polyphenolic composition: towards a total phenolic index using high-performance liquid chromatography. J Chromatogr, A., 1018 (1): 29-40. DOI: 10.1016/j.chroma.2003.08.034

Van De Velde, F., Tarola, A. M., Guemes, D., Pirovani, M. E. (2013). Bioactive compounds and antioxidant capacity of Camarosa and Selva strawberries (Fragaria $\times$ ananassa Duch.). Foods, 2 (2): 120-131.

Voća, S., Dobričević, N., Dragović-Uzelac, V., Duralija, B., Družić, J., Čmelik, Z., Skendrović Babojelić, M. (2008). Fruit quality of new early ripening strawberry cultivars in Croatia. Food Technol. Biotechnol. 46 (3): 292-298.

Wang, S. Y., Lewers, K. S., 2007. Antioxidant capacity and flavonoid content in wild strawberries. J. Amer. Soc. Hort. Sci. 132 (5): 629-637.

Zasowska-Nowak, A., Nowak, P. J., Bialasiewicz, P., Prymont-Przyminska, A., Zwolinska, A., Sarniak, A., Wlodarczyk, A., Markowski, J., Rutkowski, K. P., Nowak, D. (2016). Strawberries added to the usual diet suppress fasting plasma paraoxonase activity and have a weak transient decreasing effect on cholesterol levels in healthy non obese subjects. Journal of the American College of Nutrition, 35 (5): 422-35. 